\title{
How the Macroeconomic Theories of Keynes influenced the Development of Government Economic Finance Policy after the Great Depression of the 1930's: Using Australia as the Example
}

\begin{abstract}
By Elfriede Sangkuhl ${ }^{*}$
How the macroeconomic theories of Keynes influenced the development of Government Economic Policy after the Great Depression of the 1930's: Using Australia as the example. Keynes' economic work, The General Theory of Employment, Interest and Money, was first published in 1936. The General Theory was written as a response to the human tragedy caused by Great Depression. Keynes' General Theory was written with a view to challenging the economic orthodoxy of the times and not written with a view to practical application. The prevailing economic orthodoxy was the classical theory of economics in the Ricardian tradition. Keynes' theory became, for a time, the new orthodoxy and profoundly affected economic policy especially in the post-World War 2 period, in the Western World. Keynes prescribed a number of measures that governments should undertake to provide economic stability that could not be left to the unfettered operation of the market. For example, he explicitly proposed that taxes could be used to redistribute wealth and thus increase the propensity to consume and that taxes could be used as a form of forced corporate savings, to reduce national debt, and so, reduce the propensity to consume. In other words, taxation policy, in a package of policy measures, could be used to stimulate or slow down an economy as required. Prior to Keynes, taxation policy was more about raising funds for essential government expenditures. Keynes also propounded that interest rates in an economy be kept low so that investment in productive assets, as opposed to non-productive investment, be encouraged. This paper starts by examining Keynes' General Theory of Employment and will then illustrate how Keynesian economic theory influenced Australian government economic policy development from 1930, the pre-Keynesian era, to 1949 the height of the Keynesian era.
\end{abstract}

*Senior Lecturer, University of Western Sydney, Australia. 


\section{Introduction}

Keynes' seminal economic work, The General Theory of Employment, Interest and Money (the General Theory), was first published in 1935. The General Theory was written as a response to the human tragedy of mass unemployment and widespread poverty caused by Great Depression. In his concluding notes to his theory Keynes wrote that ' $(t)$ he outstanding faults of the economic society in which we live are its failure to provide for full employment and its arbitrary and inequitable distribution of wealth and incomes'.

Keynes' General Theory was written with a view to questioning the economic orthodoxy of the times and not written with a view to practical application. As Keynes stated in his preface to the 1936 edition, the 'main purpose is to deal with the difficult questions of theory, and only in the second place with the applications of this theory to practice'. ${ }^{2}$ Despite Keynes' protestations about the theoretical concerns of his work Galbraith, in 1952 in his work American Capitalism claimed that Keynes' final book, The General Theory of Employment, Interest and Money, shaped the course of events as only the books of three earlier economists - Smiths' Wealth of Nations, Ricardo's Principles of Political Economy and Marx's Capital - have done. ${ }^{3}$

Galbraith held that the General Theory of Keynes 'reformulated attitudes on the agitated question of the relation of the state to the economy'. 4

The economic orthodoxy during the time of the great depression was the classical theory of economics in the Ricardian tradition. ${ }^{5}$ This orthodoxy was concerned with the distribution of the given resources, (goods, income, capital) among members of a society, not with the quantum of resources available for distribution. As Ricardo stated in a letter to the economist Malthus in 1820,

Political Economy you think is an enquiry into the nature and causes of wealth - I think it should be called an enquiry into the laws which determine the division of the produce of industry amongst the classes who concur in its formation. No law can be laid down respecting quantity, but a tolerably correct one can be laid down respecting proportions. Every day I am more satisfied that the former enquiry is vain and delusive, and the latter only the true objects of the science. ${ }^{6}$

Keynes' object was the 'vain and delusive' enquiry, that is, the 'study of the forces which determine changes in the scale of output and employment as a whole'. ${ }^{2}$ Keynes' theory became, for a time, the new economic orthodoxy and profoundly affected government economic policy, including tax policy,

\footnotetext{
${ }^{1}$ Keynes (1998) 372.

${ }^{2}$ Ibid xxi.

${ }^{3}$ Galbraith (2010) 63.

${ }^{4}$ Ibid 70.

${ }^{5}$ Keynes (1998) 3.

${ }^{6}$ Ibid 4. Quoted by Keynes.

${ }^{7}$ Ibid xxii.
} 
especially in the post-World War 2 period, in the Western World. So, even though Keynes' work was not written 'with a view to practical application' his work was, this author believes, profoundly influential in shaping economic policy. For example, Keynes explicitly propounded that taxes could be used to redistribute wealth and thus increase the propensity to consume and that taxes could be used as a form of forced corporate savings, to reduce national debt, and so, reduce the propensity to consume. ${ }^{1}$ In other words, taxation policy could be used to stimulate or slow down an economy as required. Prior to Keynes, taxation policy was more about how to fairly and effectively raise funds for essential government expenditures, in keeping with the classical economic traditions of laissez faire.

After examining Keynes' economic theory this paper will illustrate how his theory influenced Australian government economic policy development from 1930, the pre-Keynesian era, to 1949 the height of the Keynesian era.

\section{Classical Economic Theory of Employment compared to the General Theory of Employment}

Keynes gave his economic work the title of 'The General Theory of Employment, Interest and Money' to distinguish it from the economic works of the classical school, his work was not to be confused with classical economic theory. Keynes called the classical school 'the followers of Ricardo, those, that is to say, who adopted and perfected the theory of the Ricardian economics, including (for example) J.S.Mill, Marshall, Edgeworth and Prof. Pigou'.

Keynes held that attempting to apply classical theory to the actual economic society in which we live would have disastrous consequences. ${ }^{3}$ Keynes saw the fundamental difference between his general theory of employment and the classical theory of employment as:

- The classical theory deals with the distribution of given ${ }^{4}$ volumes of resources between classes in society, and

- The general theory deals with the actual employment ${ }^{5}$ of available resources.

Keynes held that the great problem with the classical theory was the fact that it admitted of only two types of unemployment, vis., frictional and voluntary unemployment. ${ }^{6}$ Frictional unemployment was caused by imperfections in the competition for labour which led to short term unemployment due to time delays between demand for employment and

\footnotetext{
${ }^{1}$ Ibid 94-95.

${ }^{2}$ Ibid 3.

${ }^{3}$ Ibid.

${ }^{4}$ Ibid 4. Keynes' emphasis.

${ }^{5}$ Ibid. Keynes' emphasis.

${ }^{6}$ Ibid 6.
} 
persons taking up employment or delays caused by people training for the jobs currently in demand. Voluntary unemployment is when potential employees decide not to take on employment for the wages on offer preferring to go without work. The problem with classical theory, according to Keynes was that it does "not admit of the possibility of the third category [...] "involuntary" unemployment'. ${ }^{1}$ Classical economists had not considered the possibility of people seeking employment at current wage rates and there being no demand for their employment. Keynes put it thus:

Men are involuntarily unemployed if, in the event of a small rise in the price of wage-goods relatively to the money-wage, both the aggregate supply of labour willing to work for the current money-wage and the aggregate demand for it at that wage would be greater than the existing volume of employment. $^{2}$

Under classical economic theory there could be no involuntary unemployment because classical theory holds that the total given amount of wages available in an economy would be disbursed among the given amount of employment, labour, available in an economy. The general theory, on the other hand, holds that if the real price of goods increases above the level of real wages (as opposed to money wages) then, the resulting disequilibrium caused by the inability to sell goods would lead to less labour being required, whatever the money wage on offer: Hence, involuntary unemployment.

The fundamental difference between the classical theory of employment and Keynes' theory of employment is that under the classical theory, there can be no involuntary unemployment because the supply of labour will always find employment at the marginal cost of labour. Therefore, any 'apparent unemployment (apart from the admitted exceptions) must be due at bottom to a refusal by the unemployed factors to accept a reward which corresponds to their marginal utility.' Keynes' revolutionary conclusion was that 'a willingness on the part of labour to accept lower money-wages is not necessarily a remedy for unemployment. 4

Keynes then held that the propensity to consume and the rate of new investment determine between them the volume of employment, and the volume of employment is uniquely related to a given level of real wages - not the other way around. If the propensity to consume and the rate of new investment result in a deficient effective demand, the actual level of employment will fall short of the supply of labour potentially available at the existing real wage. ${ }^{5}$

Keynes explained how involuntary unemployment could be higher in a richer community than in a poorer one. In a poorer community the population will need to consume most of the output of the community, requiring only modest levels of investment to provide full employment. In a wealthier

\footnotetext{
${ }^{1}$ Ibid.

${ }^{2}$ Ibid 15 .

${ }^{3}$ Ibid 16 .

${ }^{4}$ Ibid 18.

${ }^{5}$ Ibid 30.
} 
community the marginal propensity to consume will be weaker, because of advanced capital accumulation and a greater level of savings, resulting in fewer opportunities for further investment resulting 'in the paradox of poverty in the midst of plenty.'1

Keynes observed that under classical economics, savings was equated to abstaining from present consumption in order to increase future consumption and that 'the resources released from preparing for present consumption could be turned over to preparing for the future consumption, ${ }^{2}$ that is, savings result in an increase of productive investments. This notion 'that current investment is promoted by individual saving to the same extent as present consumption is diminished' ${ }^{3}$ he held to be an 'absurd' fallacy leading to the 'specious' conclusion that increased savings lead to increased investments and therefore an increased demand for the production of investments. The fallacy arises

From believing that the owner of wealth desires a capital asset as such, whereas what he really desires is its prospective yield. Now, prospective yield wholly depends on the expectation of future effective demand in relation to future conditions of supply. If, therefore, an act of saving does nothing to improve prospective yield, it does nothing to stimulate investment. ${ }^{4}$

Investors, or savers, seeking a yield on their capital without increasing productive capacity, were called by Keynes, pejoratively, the rentier or the functionless investor. ${ }^{5}$ A simple example of a rentier is a share market investor who buys shares in an existing listed public company on the stock exchange. This person is seeking either a dividend or share price increase or both. This investor is not contributing to the productive capacity of the company in which she/he has invested. On the other hand, an investor buying shares in a start-up company, where the capital will be used to create productive capacity, is making a productive investment.

The crux of Keynes' general theory was that a society could reach equilibrium with a permanent level of involuntary unemployment. This equilibrium, with permanent unemployment, is the result of a deficient effective demand for consumer goods and insufficient productive investment. (Reflect on the current volume of rentier type investment versus productive investment).

\footnotetext{
${ }^{1}$ Ibid.

${ }^{2}$ Ibid 210, 211 .

${ }^{3}$ Ibid 211 .

${ }^{4}$ Ibid 212.

${ }^{5}$ Ibid 376.
} 


\section{Keynes' General Theory Prescriptions}

The popular and widely held misconception of Keynes' theory is that he simply prescribed that States operate national deficits in times of economic recession in order to stimulate demand. This was recently expressed as follows: 'Keynes' name long ago became synonymous with fiscal stimulus ('pumppriming') and deficits in times of recession. The world quickly embraced Keynesian pump-priming solutions when economies went into free fall in late $2008[\ldots]^{, 1}$ Keynes' policy prescriptions were more nuanced and targeted than simply advocating for fiscal stimulus during times of high unemployment and a shrinking economy.

Keynes proposed that in order to redress these economic failures the State needs to establish 'certain controls in matters that are now left in the main to individual initiative.' ${ }^{2}$ Keynesian economics, the economics that flourished in the post-World War II period, called on governments to develop 'a policy framework whereby the government ensures that aggregate demand is kept high enough to maintain full employment. That is, the government undertakes active demand management policy. '3 Ian Macfarlane, a former Governor of the Reserve Bank of Australia and an economist schooled in Keynesian economics in the mid 1960's, further stated that Keynes' 'prescription was to use government spending to make up for the deficiency in private spending and thereby move the economy back to full employment. ${ }^{4}$ This statement, which has been reduced to the jargon of 'pump-priming' is not what Keynes was advocating. Keynes' prescription was that in times of chronic unemployment, governments should go into deficit in order to make up for the deficiency in consumer demand and the deficiency in productive investment.

Keynes' concrete proposals were aimed at increasing the propensity to consume by way of the consumption of goods and services and the consumption of capital goods that actually increased productive capacity in society. Keynes also proposed a reduction in wealth inequality because;

1. The poor spend most, if not all, of their income and so have a far greater marginal propensity to consume than the rich, ${ }^{5}$ and

2. The savings of the rich, which are applied to non-productive investments, seeking merely a return on capital, impede the growth of wealth by impeding the growth of productive investments. ${ }^{6}$

Keynes' proposals, summarised in his concluding notes to the General Theory are:

\footnotetext{
${ }^{1}$ Carling (2013) 17.

${ }^{2}$ Keynes (1998) 377, 378.

${ }^{3}$ Macfarlane (2006) 6.

${ }^{4}$ Ibid.

${ }^{5}$ Keynes (1998) 372.

${ }^{6}$ Ibid.
} 
1. To use taxation, especially use of direct taxation, progressive income tax, surtaxes and death duties, to redress great inequalities of wealth. ${ }^{1}$ Keynes saw a danger in raising taxes, especially income taxes too high. The two considerations he had were 'the fear of making skilful evasions too much worthwhile and also of diminishing unduly the motive towards risk-taking. ${ }^{2}$ Keynes was particularly in favour of death duties because 'there are certain justifications for inequality of incomes which do not apply equally to inequality of inheritances. ${ }^{3}$

2. To set Interest rates low, so as to euthanise the functionless investor. ${ }^{4}$ Keynes' aim here was to increase the volume of capital for use in productive investment, by ensuring that the 'functionless investor will no longer receive a bonus' by way of artificially high rates of interest brought about by an artificially scarce supply if capital.

Keynes' proposals, which would allow the State to influence the rate of consumption (by taxation) and the rate of productive investment (by interest rate policies) would be insufficient to ensure an optimum rate of investment. Keynes, therefore, also proposed 'the comprehensive socialisation of investment $[\ldots]$ as $[\ldots]$ the only means of securing full employment. ${ }^{5}$ Keynes is not proposing the socialisation of all means of production. As he states:

It is not the ownership of the instruments of production which it is important for the State to assume. If the State is able to determine the aggregate amount of resources devoted to augmenting the instruments (of production) and the basic rate of reward to those who own them, it will have accomplished all that is necessary. ${ }^{6}$

Keynes' proposals, although enlarging the functions of the State and reducing the wealth disparities in society, were made with the express purpose of saving capitalism from totalitarianism. Keynes saw his prescriptions 'as the only practicable means of avoiding the destruction of existing economic forms in their entirety and as the condition of the successful functioning of individual initiative.' 7

\footnotetext{
${ }^{1}$ Ibid 372.

${ }^{2}$ Ibid.

${ }^{3}$ Ibid 373, 374.

${ }^{4}$ Ibid 375, 376.

${ }^{5}$ Ibid 378 .

${ }^{6}$ Ibid.

${ }^{7}$ Ibid 380 .
} 


\section{How Keynes' General Theory shaped Government Economic Policies in Australia - 1930 to 1949}

This paper will now examine how, in Australia, economic policy was shaped by Keynes' theory in its economic policies from the depression in the 1930 's to the post-war period. In this paper, fiscal policy will refer 'to changes in government expenditure and taxation." ${ }^{1}$ Monetary policy will refer to the quantity and price of money and credit. Monetary policy is, increasingly, concerned only with the level of interest rates, which are set by Australia's central bank, the Reserve Bank. ${ }^{2}$ Monetary policy prior to the 1970's was also concerned with bank regulation and exchange rate regulation. When examining the development of Australian government policy from the 1930's up until 1950 , there is a discernible shift from classical economic policy prescriptions toward Keynesian economic policy prescriptions. This shift was irrespective of whether the party promulgating the policies was a conservative or a labour party. In the 1930's the concern was with balancing the budget, a classical economics position. During the 1940's this became a concern with maintaining full employment and raising industrial capacity and productivity. By the time of the general election in 1949, when the government changed from a Labour government to a Liberal/Country coalition (conservative) government, both sides had been converted to Keynesian economics in their policy proposals.

\section{The 1930's and the Great Depression}

In 1930, Keynes, at the annual general meeting of the National Mutual Life Assurance Association in England (of which he was chairman), warned the shareholders of worsening financial times to come stating:

For significant signs of recovery or of further deterioration it may not be so important today to consider London or New York as to watch Australia, South America, Asia, and also Central Europe, for these areas are being reduced to very grievous distress by the combined circumstances of the fall in the prices of their chief products and the difficulty of obtaining funds on the international loan market. ${ }^{3}$

By January of 1931, Keynes said ' $I$ am sorry that my gloomy prognostications of a year ago have been more than fulfilled' ${ }^{4}$ At the time, England was a debtor country with Australia (and the other countries mentioned) being a creditor country. Australia also relied heavily on commodity prices in order to make its loan repayments. Australia faced the cessation of overseas lending and a 'catastrophic fall in [export] commodity

\footnotetext{
${ }^{1}$ Macfarlane (2006) 6.

${ }^{2}$ Ibid

${ }^{3}$ Markwell (1985) 12.

${ }^{4}$ Ibid.
} 
prices ${ }^{1}$ and sought assistance from the Bank of England, its largest creditor. In response the Bank of England sent a delegation, headed by Sir Otto Neimeyer, a classical economist, to advise the Australian government. At a conference of Commonwealth and State ministers in August 1930 it was determined to follow the advice of Niemeyer, which was to balance budgets, which included cutting public service salaries by $10 \% .^{2}$

This was a heavily deflationary prescription at a time when national income had fallen dramatically, unemployment was very high and rising, and budgets had been substantially unbalanced by a major drop in tax receipts. ${ }^{3}$

These efforts were unsuccessful. Keynes warned the British government against pressing Australia too hard and, in September 1931, proposed that

As a possible partial solution to the international debt problem that Britain "might take shipments of goods, reckoned at more reasonable prices (say 25 per cent higher) than present world prices, from such countries as India, Australia, Canada, Argentina, Germany, etc., the proceeds to be credited against the interest dues of these countries in London". 4

The Australian Commonwealth government and the State governments persisted with the Niemeyer plan for two years, attempting and failing, to balance their budget. Keynes, writing specifically of Australia, in 1932 wrote approvingly of the Niemeyer plan stating that 'I am sure that the Premiers' plan last year saved the economic structure of Australia'. However he counselled against continuing with the austerity measures of wage reductions and currency deflation stating that 'there is more chance of improving the profitableness of business by fostering enterprise and by such measures as public works than by a further pressure on money wages or a further forcing of exports'. ${ }^{6}$ This comment by Keynes foreshadowed his prescriptions in his General Theory by three years and was the first time Keynesian economics was considered in relation to Australia.

In August 1930, the first year of the Great Depression, during the second reading speech of the Appropriation Bill 1930-31, Senator Greene stated

There is one point at all events, upon which every honourable senator must be in complete agreement and that is, at whatever cost, we must this year balance our budget. We must cover our expenditure with the taxation that we raise, no matter what sacrifices have to be made. ${ }^{7}$

\footnotetext{
${ }^{1}$ Ibid.

${ }^{2}$ Ibid 13

${ }^{3}$ Ibid.

${ }^{4}$ Ibid 14.

${ }^{5}$ Ibid 20

${ }^{6}$ Ibid 21

${ }^{7}$ Commonwealth of Australia, Parliamentary Debates, Senate, 7 August 1930 (Walter Massey Greene) 5519.
} 
The senator went further, when discussing unemployment, by recommending that minimum wages be abandoned and advocated a 'return to the conditions under which private contracts (for employment) be made between man and man. ${ }^{1}$

These views, the economic norm for the times, were the classical economists' view that there is only a given volume of resources in society, and that if the market were allowed to operate unimpeded by regulations then wages would fall to a level where equilibrium, that is, full employment was reached. In the event, the Commonwealth government budget adopted for 1930-31 attempted to make up the budget shortfall by reducing the general exemption from personal income tax to $£ 150^{2}$, from $£ 300$ set in $1924^{3}$, and by cutting government expenditures. ${ }^{4}$ The States were also experiencing difficulties with repaying State government borrowings. In 1932 the States were the primary income taxing authority with the Commonwealth government having a power to levy income tax in addition to State income taxes. 5

Although the Commonwealth government had in 1915 imposed income taxes for the first time to finance the first world war 'the peacetime income tax dominance of State governments was restored during the Depression when State governments introduced special income and wage taxes on lower income ranges to finance unemployment relief and social assistance. ${ }^{6}$ For example, in ' 1938 -39 the States were collecting around $£ 30$ million annually in income taxes compared to $£ 12$ million by the Commonwealth. ${ }^{7}$ States remained the primary taxing authority in Australia until 1942, when the Commonwealth Government 'exercised its constitutional defence and grants powers to collect all income taxes in Australia. In 1942 the Commonwealth also introduced, for the first time in Australia, the "pay-as you-earn" ${ }^{, 8}$ deduction of income tax at source.

In 1931, after two years of depression and with no relief in sight, Australia held a Federal election. When comparing the election speeches from both sides of politics, the conservatives and labour, both were advocating remedies to the economic predicament of the country in classical economic terms.

The incumbent Prime Minister, James Scullin, leader of the Labour Party, in his election speech began with the efforts made by his government to improve the 'welfare of our country'. ${ }^{9}$ These efforts were directed at avoiding default with the nation's biggest creditor, Britain. The efforts included erecting tariff barriers against imports, increasing exports, especially to Britain, while at the same time securing 'British industry the largest possible share of the import

\footnotetext{
${ }^{1}$ Ibid 5520.

${ }^{2}$ Ibid.

${ }^{3}$ Mills (1925) 240.

${ }^{4}$ Commonwealth of Australia, Parliamentary Debates, Senate, 7 August 1930 (Walter Massey Greene) 5522.

${ }^{5}$ Smith (2001) 264.

${ }^{6}$ Ibid.

${ }^{7}$ Ibid.

${ }^{8}$ Hawkins (2011) 4 of 11.

${ }^{9}$ Scullin (1931) 1
} 
traded of the Commonwealth' ${ }^{1}$ of Australia. Scullin's main concern economically was to balance the budget, believing that this financial security would improve the economy and reduce unemployment. Scullin addressed the budget deficits very early in his speech, stating that for 1930-31, 'despite our economies and new taxation, there was a deficit of $£ 10,000,000$, with a prospective deficit in the present year of $£ 20,000,000^{, 2}$. Scullin's solution was for 'drastic measures [...] to retrieve the position' 3 and these measures were 'a reduction of Government expenditure: an increase in taxation, and a decrease in bank rates of interest." ${ }^{4}$ The objective of these measures were 'bright prospects of actually balancing the Budget this year. ${ }^{\text {, }}$

Joseph Lyons leader of the United Australia Party, the conservatives in opposition, berated the previous Labour government for failing to keep an agreement signed in 1930, 'a solemn agreement by the Commonwealth and the State Governments to live as closely as possible within their incomes. ${ }^{\prime 6}$ The economic plan proposed by Lyons was 'to proceed by every means within our power to balance the budget - in other words, to show that we can live within our income. ${ }^{7}$ Lyons believed that the depression in Australia could have been ameliorated had the previous government managed to live with its means. Lyons blamed the cuts to public service salaries of $20 \%$ and cuts to pensions of $12.5 \%{ }^{8}$ on the fact that the previous government failed to live within its means, thereby undermining confidence in the financial system. Schemes mooted by the previous government to print money and expend it on massive public works programmes were derided one of 'many fantastic and dangerous currency proposals'.

In the event, despite almost identical economic policies, grounded in classical economic prescriptions of balancing budgets, Lyons was elected.

\section{The 1940's and World War II}

By 1940, with Australia involved in World War II, the budget proposed 'to raise the tremendous sum of $£ 270,000,000 \ldots$ the biggest in the history of the Commonwealth. ${ }^{10}$ At the commencement of the Parliamentary session for 1940, the then Governor General ${ }^{11}$, in when opening Parliament made a speech, the main concern of which was the war. He stated that

\footnotetext{
${ }^{1}$ Ibid 5.

${ }^{2}$ Ibid 2 .

${ }^{3}$ Ibid

${ }^{4}$ Ibid.

${ }^{5}$ Ibid.

${ }^{6}$ Lyons (1931) 3

${ }^{7}$ Ibid 6.

${ }^{8}$ Ibid 3.

${ }^{9}$ Ibid.

${ }^{10}$ Commonwealth of Australia, Parliamentary Debates, Senate, No. 48, 1940, 28 November 1940 (Joseph Silver Collings). 235.

${ }^{11}$ Commonwealth of Australia, Parliamentary Debates, Senate, No. 47, 1940, 20 November 1940, Preface to the Day's Proceedings (Governor-General). The Governor General was His Excellency General the Right Honourable Alexander Gore Arkwright, Baron Gowrie.
} 
The principal business which you will now be asked to consider in the early part of this session will be the making of financial provision for the carrying on on the war and for the ordinary civil services of government. The Treasurer (Mr. Fadden) will, within a few days lay before you a budget which will impose upon the Australian people a financial burden heavier than they have ever been called upon to bear. I am confident that these burdens will be cheerfully accepted and successfully borne. ${ }^{1}$

The Governor-General was using the language of the classical economists that had preceded Keynes, in assuming that the burdens will be met by the people of Australia. There is no possibility in this thinking that the government might run a deficit budget to pay the extraordinary cost of the war. When the budget was released it did provide for government borrowings which were debated in parliament using Keynesian language. Senator Collings, defending the need for the country 'to swallow increasing doses of national credit' to make the necessary expenditures stated

I submit emphatically that the policy of spending less is an exploded fallacy [...]. If we expend less there will be less production, industries will languish, unemployment will increase, and the national income will contract [...]. We are here to spend money, and spend we must. ${ }^{2}$

Senator Collings does not explicitly state that he is following the Keynesian prescriptions for economic growth, but he does appear to have adopted the Keynesian approach to meet the economic challenges facing Australia in 1940. Note, Senator Collings was the Senate leader of the opposition, that is, the Labour Party, defending the conservative party's planned budget deficit. ${ }^{3}$

Australia was governed by conservative parties from 1931 till October 1941. ${ }^{4}$ In 1941 the Labour party became the governing party 'after two independents holding the balance of power withdrew their support from the conservative coalition led by Fadden'. 5 In the general election of $1943^{6}$ the Labour party was elected into government.

In 1942 the Labour government took over the power 'as the sole imposer of income tax ${ }^{7}$ and took control of the Commonwealth Bank. ${ }^{8}$ The Bank's

\footnotetext{
${ }^{1}$ Ibid 7.

${ }^{2}$ Commonwealth of Australia, Commonwealth of Australia, Parliamentary Debates, Senate, No. 48, 1940, 28 November 1940 (Joseph Silver Collings) 235.

${ }^{3}$ Ibid, Preface to the Day's Proceedings.

${ }^{4}$ Hawkins (2011) 4.

${ }^{5}$ Ibid.

${ }^{6}$ Commonwealth of Australia, Australia's Prime Ministers, National Archives of Australia, <http://primeministers.naa.gov.au/primeministers/>.

${ }^{7}$ Hawkins (2011) 4 of 11.

${ }^{8}$ Ibid 5 .
} 
powers were increased so that it could conduct 'market operations' 1 in competition with private savings banks, private banks were obliged to lodge funds with the Commonwealth Bank and comply with lending policies promulgated by the Commonwealth Bank. In addition, the 'Commonwealth Bank was also empowered to set maximum interest rates on bank deposits and advances. $^{2}$

1943 was a time of political turmoil in the conservative parties, resulting in the leader of the Country Party, Arthur Fadden, becoming the leader of the conservative coalition and contesting the election against John Curtin the leader of the Labour party. The general election of 1940 had returned a conservative government headed by Robert Menzies, the then leader of the United Australia Party. By 1941 Fadden was leading the conservative coalition but lost government to Labour, led by Curtin, when the two independents changed their allegiance. So, Curtin was contesting the election as Prime Minister even though Labour had not won the election of $1940 .^{3}$

Comparing the election speeches, during that contest, the main concern was the Australian war effort. Fadden, in economic matters was still largely and not very coherently, adopting a classical economist's viewpoint. Fadden did not make specific economic promises but attacked government borrowings because he saw that as inflationary, the 'inflation menace', ${ }^{4}$ and a scourge that robs people of their savings. He also addressed the recent depression stating that the parties he represented 'pledge themselves to aim at stability of employment after the war'. ${ }^{5}$ However, how that stability was to be achieved was quite vague. Fadden deplored high rates of taxation and his economic policy was basically a promise to 'cut out extravagance in Government expenditure and adopt a properly balanced plan of taxation, loans and post-war credits, assisted where necessary, by appropriate use of Central Bank resources'. ${ }^{6}$ So, it appears that Fadden was still a classical economist in his policy prescriptions.

John Curtin of the Australian Labour party, Fadden's opponent, and eventual winner of the election, presented a more coherent economic policy and one that was unapologetically Keynesian in its policy prescriptions. Curtin stated that in order to finance the war the entire resources of the country had been marshalled by way of increased taxation, voluntary public loans (war bonds) and government borrowing from the central bank. ${ }^{7}$ Curtin stated that the economic approach of his government during and after the war would be one where 'The Labour government has looked steadily at the real facts of national economy, and has adjusted financial methods to our needs, instead of letting our lives and our needs be distorted by financial limitations. ${ }^{8}$

\footnotetext{
${ }^{1}$ Ibid.

${ }^{2}$ Ibid.

${ }^{3}$ Fadden (1943) 1.

${ }^{4}$ Ibid 10

${ }^{5}$ Ibid 11 .

${ }^{6}$ Ibid.

${ }^{7}$ Curtin (1943) 9.

${ }^{8}$ Ibid.
} 
The speech went on to propose very Keynesian policy prescriptions to ensure full employment and income protection for the needy after the war. ${ }^{1}$ These prescriptions included government capital works, ${ }^{2}$ the establishment of a National Welfare Fund, ${ }^{3}$ price controls on essential items accompanied by subsidies to producers ${ }^{4}$ as well as government borrowings when considered necessary to achieve these proposals.

By the time of the 1946 budget the tension between the classical approach and the Keynesian approach had all but been vanquished in favour of Keynes. The Prime Minister and Treasurer, the Right Honorable Joseph Chifley, in his opening remarks to the budget of 1946 gave a thoroughly Keynesian explanation of the budget proposals. He stated

Full employment gives wage-earners secure tenure of their jobs and provides industrialists with dependable markets for their goods. Government policy has been and will be steadily directed toward this end. ${ }^{6}$

The budget's taxation proposals were all directed to increasing the propensity to consume and in assisting Australian manufacturing to increase productive capacity. Indirect taxes, sales taxes, customs duties and excise taxes were reduced in a targeted manner. No direct taxes were reduced because personal income tax cuts had been made prior to handing down the budget. ${ }^{7}$ These income tax cuts were made to release pent up consumer demand built up during the duration of the war.

The Labour government did indeed follow the policies outlined in the 1943 election speech. The 1946 budget reduced or abolished sales taxes on consumer goods, notably clothing, drapery, soft furnishings, yarn, watches, clocks, musical instruments, gramophones, soap and toothpaste ${ }^{8}$ Principal foodstuffs were already exempt from sales tax. The government also exempted most building materials from sales tax ${ }^{9}$ due to the housing shortage after the war. Customs and excise duties were reduced or abolished on plant, equipment, materials and articles used in connexion with manufacturing. ${ }^{10}$ Customs and excise duties on petrol were reduced ${ }^{11}$ to assist industry and consumers. Chifley summarised the thrust of the indirect tax cuts by restating his budget aims 'Practically all essential commodities entering into the living standard

\footnotetext{
${ }^{1}$ Ibid 9-10.

${ }^{2}$ Ibid 10 .

${ }^{3}$ Ibid 11 .

${ }^{4}$ Ibid 8 .

${ }^{5}$ Ibid 9.

${ }^{6}$ Commonwealth of Australia, Parliamentary Debates, House of Representatives, No. 46, 1946, 14 November 1946 (Joseph Benedict Chifley) 243.

${ }^{7}$ Ibid 247.

${ }^{8}$ Ibid 257.

${ }^{9}$ Ibid.

${ }^{10}$ Ibid 246.

${ }^{11}$ Ibid 247.
} 
will be free from sales tax. The customs and excise reductions will also benefit consumers directly and will reduce costs of both current production and the establishment of new enterprises'. ${ }^{1}$

The budget tax cuts were made up as follows:

$\begin{array}{ll}\text { Income Tax on Individuals } & £ 37,000,000 \\ \text { Sales Tax } & £ 20,000,000 \\ \text { Customs and excise } & £ 4,000,000\end{array}$

The income tax cuts, made prior to the handing down of the budget, in July of 1946, were 'given through a graduated reduction of rates' 2 and by raising the tax free income threshold. For a single income tax payer the tax free threshold rose from $£ 266$ per annum to $£ 280$, for a person with a dependant wife and two children the tax free threshold rose from $£ 380$ to $£ 412$. $^{3}$ Tax reductions had been made in the previous year and the effect was 'an overall reduction of 22 per cent from the peak war-time rates first enacted in 1943. ${ }^{4}$ The tax cuts were proportionally far higher for low income earners, in keeping with Keynes' prescriptions to relieve the poor because of their greater propensity to consume. The reductions in income tax 'range from more than 47 per cent on the lowest incomes to something under 20 per cent on incomes exceeding $£ 1,500$, 5 per annum.

The expenditure side of the budget was also targeted to increasing consumer demand and productive capacity. The government directed loan funds to the States in order to 'cover expenditure by State governments on public works and housing' ${ }^{6}$ The government also funded price subsidies on essentials such as potatoes, tea, milk, imported textiles, wool and basic wage support. Assistance was also given to primary industries by way of direct subsidies. ${ }^{7}$

The government also maintained pensions, child endowment, unemployment benefits, hospital and pharmaceutical benefits and housing rental rebates. $^{8}$ In July of 1946 the invalid and old age pensions and widows' pensions were all increased, the means test rules were liberalised and the amount of income a pensioner could earn before having his/her pension reduced was increased..$^{9}$ Although income tax rates were reduced from the high wartime levels, progressivity of tax rates was maintained. The government also

\footnotetext{
${ }^{1}$ Ibid 247.

${ }^{2}$ Commonwealth of Australia, Parliamentary Debates, House of Representatives, No. 28, 1946, 12 July 1946 (Joseph Benedict Chifley) 2451.

${ }^{3}$ Ibid 2464.

${ }^{4}$ Ibid 2451-2452.

${ }^{5}$ Ibid 2452.

${ }^{6}$ Commonwealth of Australia, Parliamentary Debates, House of Representatives, No. 46, 1946, 14 November 1946 (Joseph Benedict Chifley) 246.

${ }^{7}$ Ibid 251.

${ }^{8}$ Ibid.

${ }^{9}$ Commonwealth of Australia, Parliamentary Debates, House of Representatives, No. 28, 1946, 12 July 1946, 2451
} 
passed the Commonwealth Bank Act (1946) in order that the Commonwealth Bank had a central bank function and provided competition to the other trading banks operating in Australia. The Bank was to ensure full employment through judicious use of monetary policy, that is, control of money supply and interest rates.

\section{9 and the General Election}

The economic policies of the Chifley Labour government were, by 1946, full informed by Keynesian economic theory. However, the 1949 general election saw a return of a conservative government. However, as can be seen by the election speeches of the two party leaders at that time, the change of government was not a rejection of Keynesian economic policies and policy prescriptions.

The speech of the incumbent Labour Prime Minister, Ben Chifley, opened with a review of the government's achievements since attaining power in 1941 and with their future plans. The speech then went straight to Labour's economic achievements and plans. ${ }^{1}$ The government's achievements were stated as:

Full employment has been maintained. The economy has been strengthened against the possibility of depression. A wide system of social services now offers protection to the individual against misfortunes of unemployment, sickness and old age. Great headway has been made with the migration programme. Huge developmental projects have been put in hand to open new resources and provide the foundation for the expansion of all kinds of industries. ${ }^{2}$

Chifley went on to raise fear of the opposition by stating that they would undo the good works of the government by a return to classical economics. The opposition view was stated as a belief that 'a degree of unemployment' would be good for business. Chifley demolished that criticism with a Keynesian argument, that the 'Labour Government rejects this barbarous and intolerant view and dismisses as absurd the arguments used to support it. It is utter nonsense to say that unemployment would cure shortages - produce more goods, that is, by having fewer people at work. ${ }^{3}$

Robert Menzies, the leader of the conservative opposition, and subsequent winner of the election, opened his speech with an attack on the Labour Governments' 'socialisation of industry, production, distribution and exchange. ${ }^{4}$ The first four pages of Menzies' speech was an attack on the dangers of socialism. ${ }^{5}$ At that time, the spectre of communism was perceived

\footnotetext{
${ }^{1}$ Chifley (1949) 1.

${ }^{2}$ Ibid 2 .

${ }^{3}$ Ibid 3.

${ }^{4}$ Menzies (1949) 2.

${ }^{5}$ Ibid 1-4.
} 
as a threat to freedom ${ }^{1}$ and the subsequent Menzies government even attempted, unsuccessfully, to outlaw the Australian Communist Party. Menzies said of Communists that they 'are the most unscrupulous opponents of religion, of civilised government, of law and order, of national security. Abroad, but for the threat of aggressive Russian Imperialism, there would be real peace today. 2

Robert Menzies, however, did not propose the winding back of Keynesian economic policy prescriptions that had been put in place by the Labour Government. In fact Menzies assured voters that 'We shall confidently devote ourselves to full employment and the avoidance of depression'3 (Menzies' emphasis). Menzies states that to ensure full employment into the future his government would 'use public works to the full' 4 and instigate interlocking policies to stabilise and develop primary industry, industrial production, ensuring adequate rural and urban housing, improving transport and ensuring the supply of industrial inputs. ${ }^{5}$ By the time of the budget of 1951 Menzies stated that 'there is great force in that view'; ${ }^{6}$ the view 'that in a depression the Government ought to budget for a deficit, that it ought to use Central Bank Credit for works." 7 Menzies was applying the same Keynesian argument to his 1951 budget, a budget in a time of an 'inflationary boom'. ${ }^{8} \mathrm{He}$ was advocating 'a surplus in the Budget at a time like this for sound economic reasons'. ${ }^{9}$ That surplus, with the objective of limiting demand for goods, was to be provided by an increase in taxation ${ }^{10}$, placing the burden on 'the richer sections of the community. ${ }^{11}$ The taxation proposals included increases in income taxes, sales tax and excise taxes on luxury and non-essential good and by revaluing land for the imposition of land tax at new values. ${ }^{12}$

\section{Conclusion}

Australia gradually adopted the Keynesian approach in order to redress the worst effects of the depression and continued with the Keynesian approach in the post-World War II period. Macfarlane stated that during the post-World War II period it was felt that Keynesian economics was the solution to macroeconomic problems 'with the problems of the developed countries largely solved" ${ }^{13}$ and that success engendered 'an enormous feeling of

\footnotetext{
${ }^{1}$ Ibid 7.

${ }^{2}$ Ibid.

${ }^{3}$ Ibid 5.

${ }^{4}$ Ibid.

${ }^{5}$ Ibid.

${ }^{6}$ Menzies (1951) 20.

${ }^{7}$ Ibid.

${ }^{8}$ Ibid.

${ }^{9}$ Ibid 19.

${ }^{10}$ Ibid 3.

${ }^{11}$ Ibid 5 .

${ }^{12}$ Ibid 6.

${ }^{13}$ Macfarlane (2006) 6.
} 
confidence in the economics profession at that time'. In the 25 year period immediately after World War II, the developed world experienced what was heralded as a Golden Age. ${ }^{1}$ In Australia, for example, 'the period was one where most of the time the unemployment rate was about 2 per cent, and the inflation rate about 3 per cent'. ${ }^{2}$ This 'golden age' was, in part, attributed to the adoption of Keynesian economics. However, the stagflation of the 1970's, a period of high inflation and, relatively, high unemployment appeared resistant to the Keynesian economic prescriptions. The 1970's heralded a new era in economic thought, neoliberalism.

\section{References}

Carling, R. (2012-2013). 'Keynes, Hayek and the Great Recession'. Policy, Vol. 28 (4).

Chifley, B, (1949) Election Speech 1949, (Speech delivered at Canberra on, 14 November, 1949), Museum of Australian Democracy, Democracy, <http://elec tionspeeches.moadoph.gov.au/speeches/1943-ben-chifley>,

Commonwealth of Australia, Australia's Prime Ministers, National Archives of Australia, <http://primeministers.naa.gov.au/primeministers/>

Commonwealth of Australia, Parliamentary Debates, Senate, 7 August 1930

Commonwealth of Australia, Parliamentary Debates, Senate, No. 47, 1940, 20 November 1940.

Commonwealth of Australia, Parliamentary Debates, Senate, No. 48, 1940, 28 November 1940.

Commonwealth of Australia, Parliamentary Debates, House of Representatives, No. 28, 1946, 12 July 1946.

Commonwealth of Australia, Parliamentary Debates, House of Representatives, No. 46, 1946, 14 November 1946.

Curtin, J. (1943). Election Speech 1943, (Speech delivered on, 26 July, 1943), Museum of Australian Democracy, Democracy, <http://electionspeeches.moado ph.gov.au/speeches/1943-john-curtin>

Fadden, A. (1943) Election Speech 1943, (Speech delivered at Brisbane, 22 July, 1943), Museum of Australian Democracy, Democracy, <http://electionspeeches. moadoph.gov.au/speeches/1943-arthur-fadden>

Galbraith, J. K. (2010). The Affluent Society and Other Writings, The Library of America.

Hawkins, J. (2011). 'Ben Chifley: The True Believer', Economic Roundup, Issue 3, The Treasury, <http://www.treasury.gov.au/PublicationsAndMedia/Publications/ 2011/Economic-Roundup-Issue-3>

Keynes, J.M. (1998). The General Theory of Employment, Interest and Money, Macmillan Cambridge University Press.

Macfarlane, I. (2006). The Search for Stability: Boyer Lectures 2006, ABC Books Australia.

Markwell, D. J. (1985). 'Keynes and Australia' (Research Discussion Paper 2000-04, Research Department, Reserve Bank of Australia, and New College, Oxford ),

${ }^{1}$ Ibid 4.

${ }^{2}$ Ibid 5. 
presented at a seminar in the research department of the Reserve Bank of Australia, 18 September, 1985.

Menzies, R. (1949). Election Speech 1949, (Speech delivered at Melbourne on, 10 November, 1949), Museum of Australian Democracy, Democracy, <http://elec tionspeeches.moadoph.gov.au/speeches/1943-robert-menzies>,

Menzies, R. (1951). The Budget's Attack on Inflation', a speech delivered in the House of Representatives, 3 October, 1951, issued by The Federal Secretariat of the Liberal Party of Australia

Mills, S. (1925). Taxation in Australia, London: Macmillan and Co., Limited.

Porter, E. (2014). 'A Relentless Widening of Disparity in Wealth', The New York Times, March 11, 2014.

Sabine, B.E.V. (1966). A History of Income Tax. London: George Allen \& Unwin Limited.

Scullin, J. (1931), Election Speech 1931, (Speech delivered at Melbourne, 1 December, 1931), Museum of Australian Democracy, Democracy, <http://elec tionspeeches.moadoph.gov.au/speeches/1931-james-scullin>

Smith, J.P. (2000). 'Progressivity of the Commonwealth Personal Income Tax, 19171977', The Australian Economic Review, September 2001, vol. 34 (3).

United Nations (2011). World Economic Situation and Prospects 2012: Global economic outlook. New York: United Nations.

Wapshott, N. (2011). Keynes Hayek: The Clash that Defined Modern Economics. New York, London: W.W. Norton \& Company. 
